\title{
Un approccio collaborativo di tipo BIM per colmare distanze fisiche, sociali e culturali
}

\author{
Anna Sanseverino \\ Victoria Ferraris \\ Davide Barbato \\ Barbara Messina
}

\section{Abstract}

Il paper illustra gli esiti di un'esperienza rivolta, come primo livello di destinatari, agli studenti dell'insegnamento di Informatica Grafica del Corso di Laurea Magistrale in Ingegneria Edile-Architettura dell'Università di Salerno e incentrata sul tema della rappresentazione di dati integrati mediante un approccio di tipo BIM. In particolare, sfruttando le peculiarità di una didattica a distanza imposta dall'emergenza sanitaria in corso, incentrata su una triangolazione "Sud Italia - Sudamerica - Sudafrica" è stata testata la capacità di scambio e interazione internazionale e interuniversitaria tra docenti e studenti chiamati, in questa situazione, a sviluppare attività grafiche di gruppo. II caso studio selezionato è la Coromandel House, in Sudafrica, di Marco Zanuso - considerato tra i padri fondatori del design industriale italiano - per la quale sono stati realizzati modelli intesi quali contenitori di informazioni. II metodo proposto ha previsto in una prima fase una modellazione cooperativa e l'elaborazione di render mediante applicativi user friendly. Gli elaborati grafici prodotti e la documentazione esistente sono poi confluiti in un database informativo collegato al modello 3D, secondo un approccio di tipo OpenBIM in grado di rendere il modello accessibile e facilitare così uno scambio culturale e formativo continuo.

Parole chiave

linguaggio, metodologia tecnica, open BIM, IFC, Coromandel House.

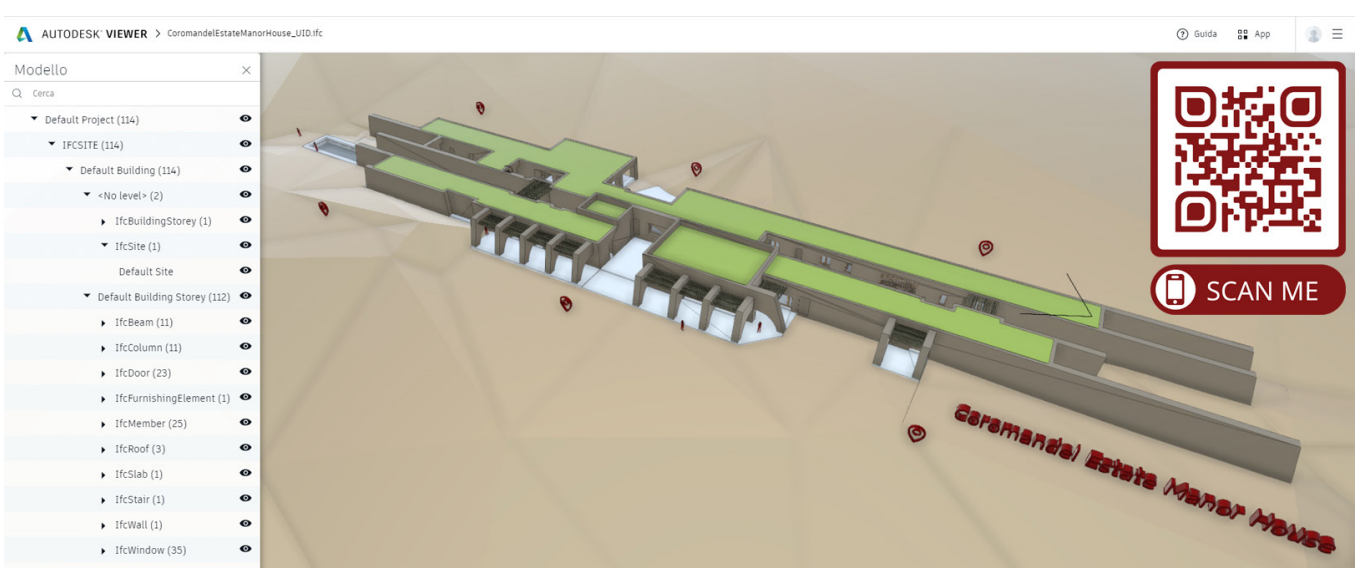




\section{Introduzione}

II presente lavoro si propone come momento di riflessione a valle dell'esperienza svolta nell'ambito dell'insegnamento di Informatica Grafica per il Corso di Laurea Magistrale in Ingegneria Edile-Architettura dell'Università degli Studi di Salerno, che ha visto la collaborazione dei docenti del gruppo di Disegno con visiting professors dell'Universidad Nacional de Córdoba. Lo scopo del corso è stato quello di introdurre i futuri architetti e ingegneri alla metodologia tecnica BIM.

L'utilità didattica di sviluppare le competenze grafico-progettuali degli studenti mediante un approccio di tipo BIM è argomento alquanto dibattuto. I diversi studi condotti in tale ambito [Banfi 2017; Calvano 2016; Osello 2012; Sacchi 2016] si soffermano sulle nuove possibilità offerte da tale metodologia: queste consistono innanzitutto nella capacità di visualizzare lo spazio tridimensionale, non solo come volumetria, ma anche come insieme degli elementi costruttivi che lo compongono. Al contempo però, sfruttando la logica della interoperabilità delle informazioni e dei dati correlati, il BIM affına la capacità collaborativa degli studenti che imparano così a lavorare in modo partecipato e integrato [Lo Turco 201 I; Yousefzadeh 20 I 5]. La Coromandel Estate Manor House [https://architizer.com; http://hiddenarchitecture.net], edificata in Sudafrica su progetto dell'architetto Zanuso, si presenta come caso studio particolarmente indicato per analizzare i risultati scaturiti dalla commistione di culture differenti e testare l'efficacia dell'approccio suggerito (fig. I). In particolare, lo studio intende analizzare strutture in muratura portante, tipiche della tecnologia costruttiva locale tradizionale, con il supporto dei moderni strumenti di indagine e, al contempo, risolvere il dualismo tra due discipline complementari quali l'ingegneria e l'architettura. Inoltre, l'esercizio accademico ha permesso di confermare l'importanza del lavoro di gruppo, di un approccio interdisciplinare e i benefici di una metodologia di tipo BIM (Building Information Modelling) come strumento di analisi e ricerca [Comisión es. BIM 20I8].

II metodo grafico proposto ha previsto un approccio di tipo speditivo, procedendo direttamente a una modellazione del manufatto architettonico in SketchUp. Al modello geometrico così elaborato è stato poi sovrapposto un primo layer informativo, consistente nella texturizzazione degli elementi costruttivi. II lavoro è sfociato quindi nella realizzazione di una serie di rendering sviluppati singolarmente dagli studenti, tramite l'applicativo Enscape per SketchUp. Gli elaborati grafici cosi prodotti sono infine confluiti - insieme all'esistente documentazione scritta, grafica e fotografica del sito, pubblica e non - in un sistema di informazioni collegato al modello tridimensionale, operando dunque secondo i dettami della tecnologia BIM [Sacks et al. 2018].

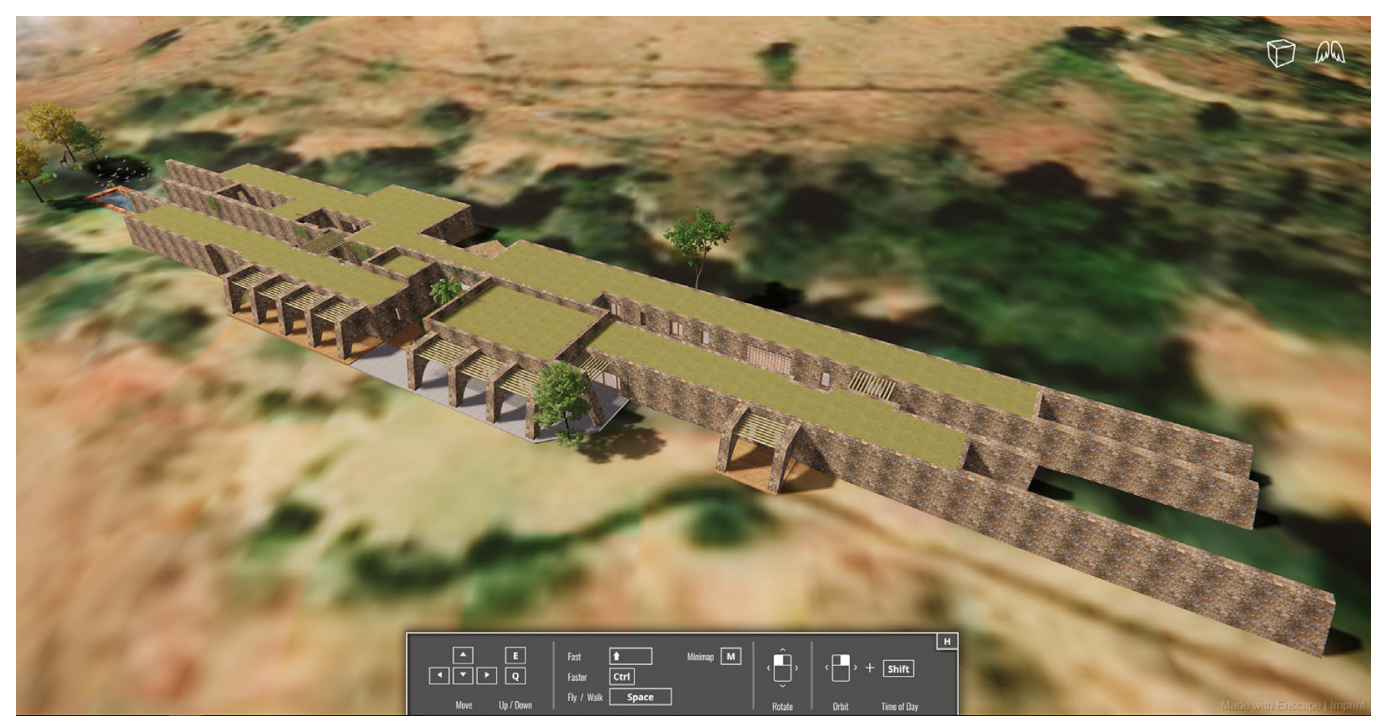




\section{II manufatto architettonico}

Marco Zanuso, architetto e disegnatore industriale italiano, è riuscito, attraverso la ricerca e l'esplorazione di diverse soluzioni tipologiche, a interpretare il paesaggio, il clima e la tecnologia costruttiva locale di Mpumalanga in Sudafrica [Barba 2016], in modo da trasformare il suo progetto in una proposta che racchiude tanto lo spazio costruito quanto il contesto naturale che lo circonda [Steyn 20 I6]. In particolare, combinando esigenze di tipo ambientale - come le condizioni climatiche - con le richieste della committenza, ha saputo affrontare in maniera originale ed efficiente il tema della residenza privata, che assurge in questo caso a esempio magistrale di architettura regionale sudafricana.

La Coromandel Estate Manor House è il connubio dei sogni di un cliente sudafricano - mosso da un forte interesse per l'architettura - e la risposta sensibile di un progettista in grado di interpretare un paesaggio e una cultura non sua, che si traduce in un'opera degna di valore.

Rappresenta l'interazione tra differenti mondi, aree di studio, idiosincrasie, ma sopra ogni cosa la ricerca della soluzione ottimale a un problema non solo architettonico, ma prevalentemente paesaggistico e climatico. "Il viaggio attraverso la casa è misterioso, stretti percorsi ventosi si insinuano nella possente struttura muraria intagliata in pietra dolerite e adagiata lungo un versante ascendente collinare. Concettualmente la casa riflette le qualità di una città italiana, il cui cuore, come una piazza rappresenta il punto di confluenza dei passaggi sinuosi che conducono alla parte più privata, le camere da letto. Per far fronte al forte soleggiamento locale la struttura è caratterizzata da zone d'ombra, zone verdi e specchi d'acqua. La casa può dunque essere descritta come una drammatica manipolazione del paesaggio atta a offrire pratici e periodici punti di ristoro organizzati attraverso spazi e linee razionali'" [Peres 20 I3].

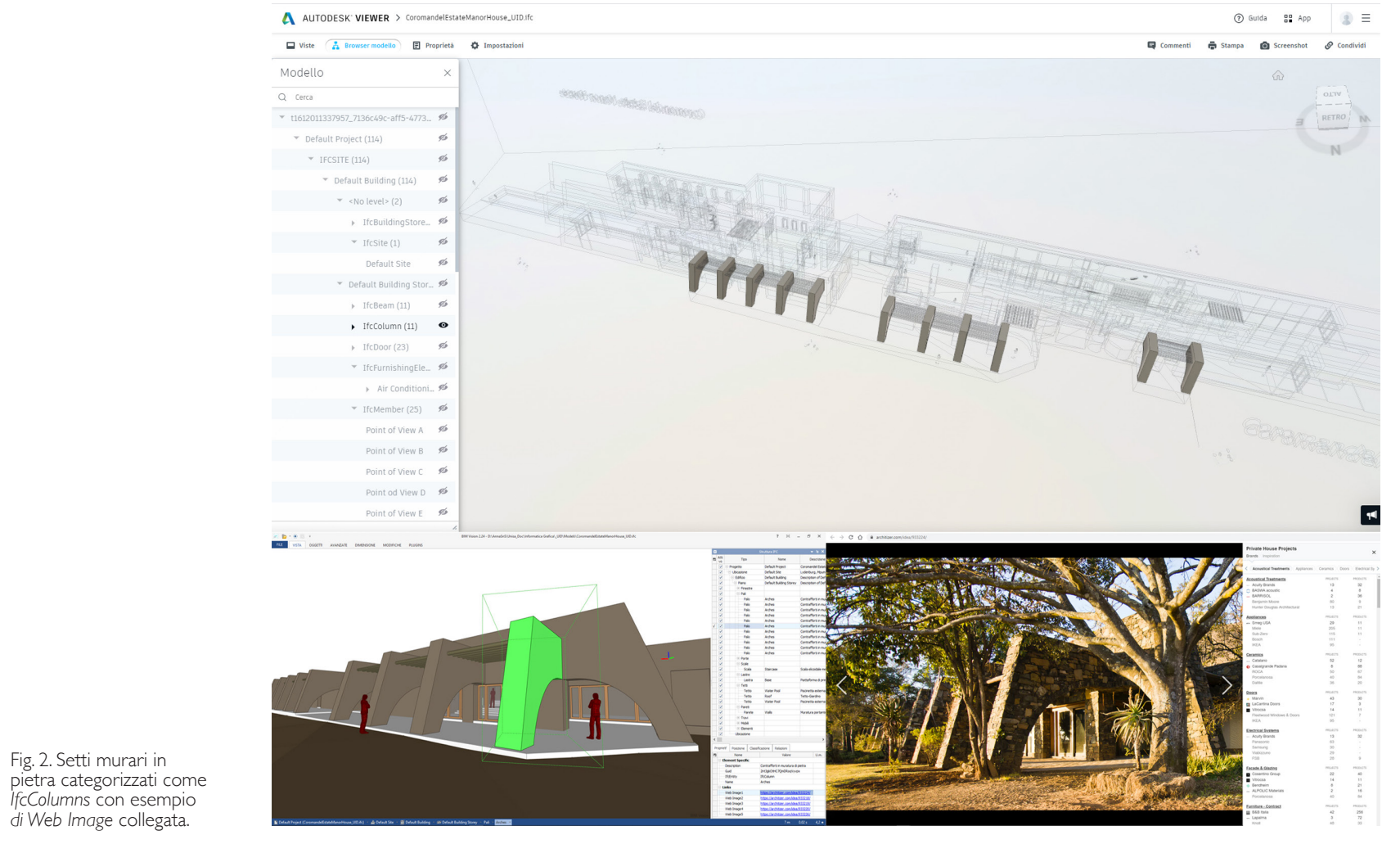

\section{Metodologia: l'ambiente di lavoro}

L'emergenza sanitaria che stiamo vivendo ha indubbiamente favorito l'informatizzazione dell'intero sistema educativo, affidandosi alle molteplici piattaforme presenti in rete e ai tools a esse correlati. Se però tale situazione ha fatto sì che tutti fossero un po' più lontani, la tecnologia oggi a disposizione ha messo in luce anche i diversi vantaggi legati a 
Fig. 3. Contesto territoriale in formato IfcSite e relative proprietà collegate (Links).

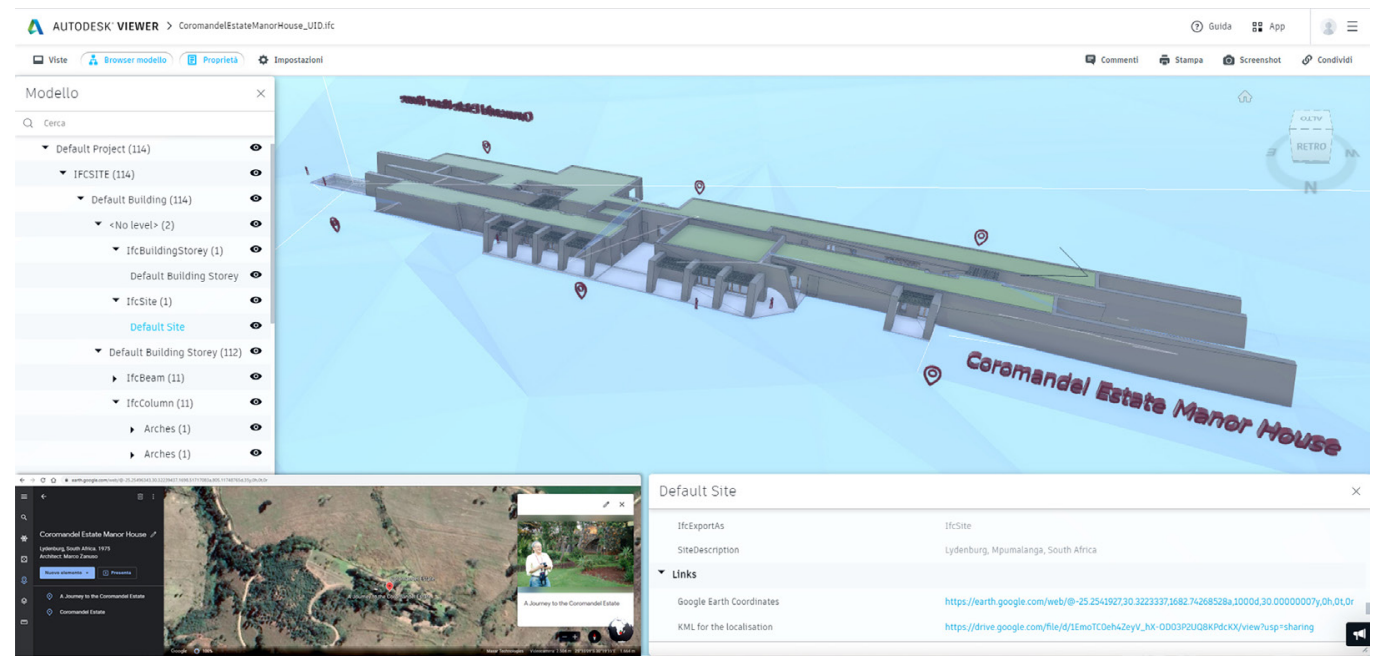

forme e strumenti di didattica a distanza, finora poco utilizzate dagli Atenei di tipo tradizionale. Prima tra tutti la capacità di avvicinare digitalmente gli utenti e permettere loro di condividere informazioni e dati in tempo reale, secondo approcci basati sul principio della interoperabilità. La piattaforma Microsoft Teams ha dunque ospitato le lezioni e le attività pratiche e laboratoriali rivolte agli studenti del terzo anno del Corso di laurea magistrale in Ingegneria Edile-Architettura dell'Università degli Studi di Salerno.

Se da un lato l'esperienza didattica ha evidenziato una grande efficacia in termini pratici e operativi, consentendo la condivisione di materiale grafico, immagini e informazioni di varia natura inerenti all'architettura scelta come esempio su cui testare l'approccio digitale seguito, dall'altro ha permesso di colmare la distanza fisica tra 3 paesi - Italia, Argentina e Sudafrica - che su tale tema hanno avuto modo di confrontarsi nell'ambito di un progetto di cooperazione internazionale [I] trovando un "terreno comune" nel quale incontrarsi e dialogare. Infatti, i dati raccolti nel corso delle numerose visite congiunte di studenti e docenti delle università coinvolte - nei mesi che hanno preceduto l'emergenza sanitaria mondiale - sono stati digitalmente condivisi al fine di permettere una più profonda comprensione del luogo e dell'architettura da rappresentare. Con riferimento all'ambiente software, ci si è orientati su SketchUp della Trimble, guardando da un lato all'accessibilità dal punto di vista economico - il costo ridotto lo fa rientrare infatti in una fascia di mercato accessibile anche ai non professionisti - dall'altro all'interfaccia grafica user-friendly, alla sua nota diffusione e compatibilità con la maggior parte dei motori di rendering commerciali. Altro aspetto considerato è la possibilità offerta da tale software di svolgere una modellazione che rispetti i criteri di un'applicazione tecnologica di tipo BIM, semplicemente operando piccoli accorgimenti e scegliendo con attenzione gli strumenti da adottare.

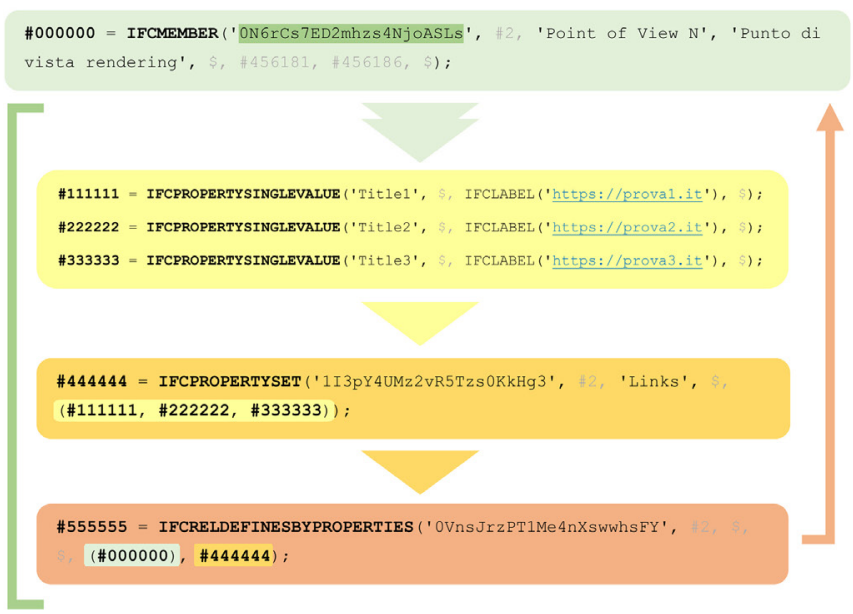


Fig. 5. Risultato dell'editing di un file IFC per

collegamento dei render Point of View predisposti.

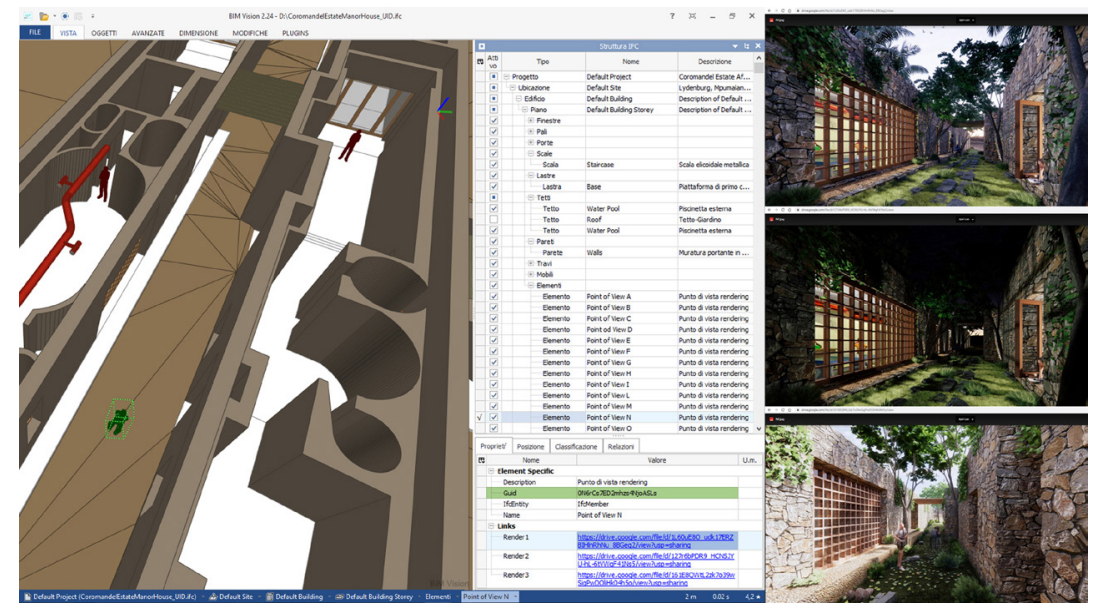

Un approccio conforme alla metodologia tecnica di tipo BIM

Note le peculiari caratteristiche dell'oggetto di studio, l'irregolarità strutturale, la forte anisotropia degli spazi interni e la materialità assorbita e fusa con il contesto ambientale, si è riconosciuto un primo vantaggio oggettivo nella scelta software, consistente nell'agevolezza con la quale è stato possibile restituire le geometrie complesse dello spazio costruito e del contesto da rappresentare.

L'approccio collaborativo ha seguito indubbiamente i dettami della metodologia BIM: una modellazione di tipo object-oriented, parametrica e informativa. A tale scopo, gli elementi costruttivi che compongono la Estate Manor sono stati discretizzati e organizzati in componenti, secondo il paradigma object-oriented. Tramite l'impiego di tool gratuiti, interni all'ambiente software prescelto, sono stati poi modellati in modo parametrico gli elementi di finitura che richiedono un livello di dettaglio più elevato, quali infissi e scale elicoidali, comunque ridimensionabili a posteriori.

Un primo tipo di informazione collegata al modello così strutturato è stata la geolocalizzazione, con accesso diretto da SketchUp alla mappa del sito disponibile in Google: di questo è stata quindi ricostruita l'orografia, seppur semplificata, per la necessaria fase di contestualizzazione.

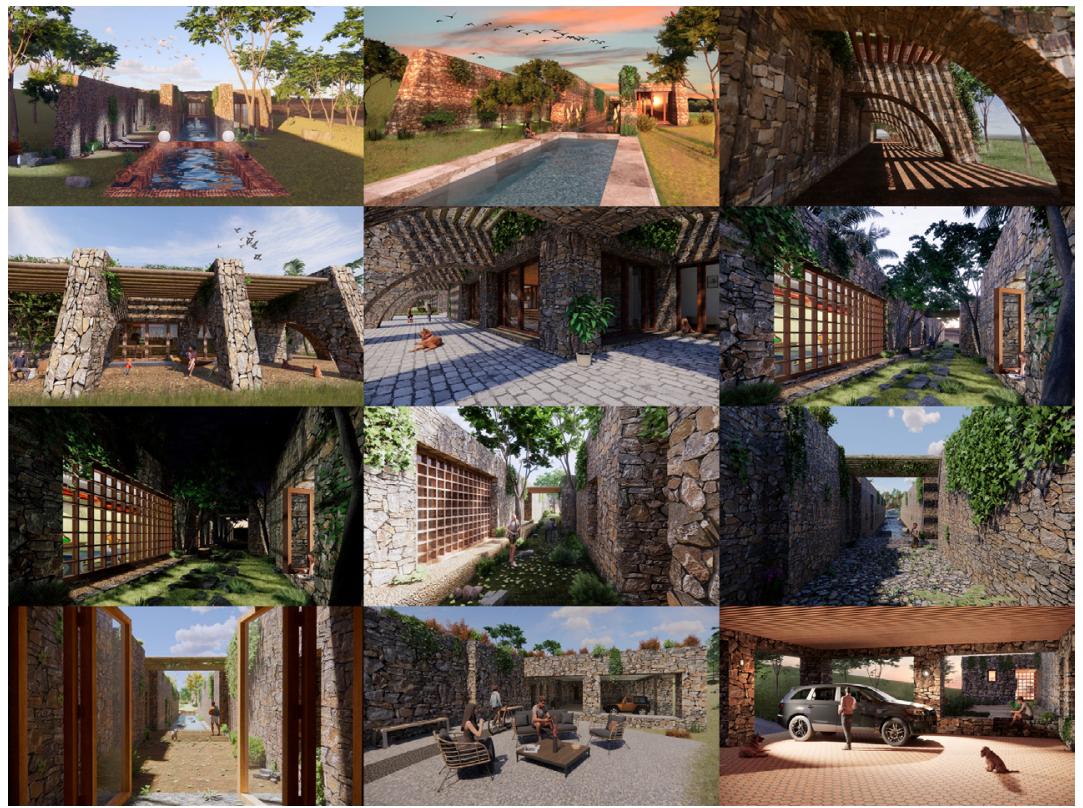


Fig. 7. Immagini

renderizzate degli interni prodotte individualmente dagli studenti.

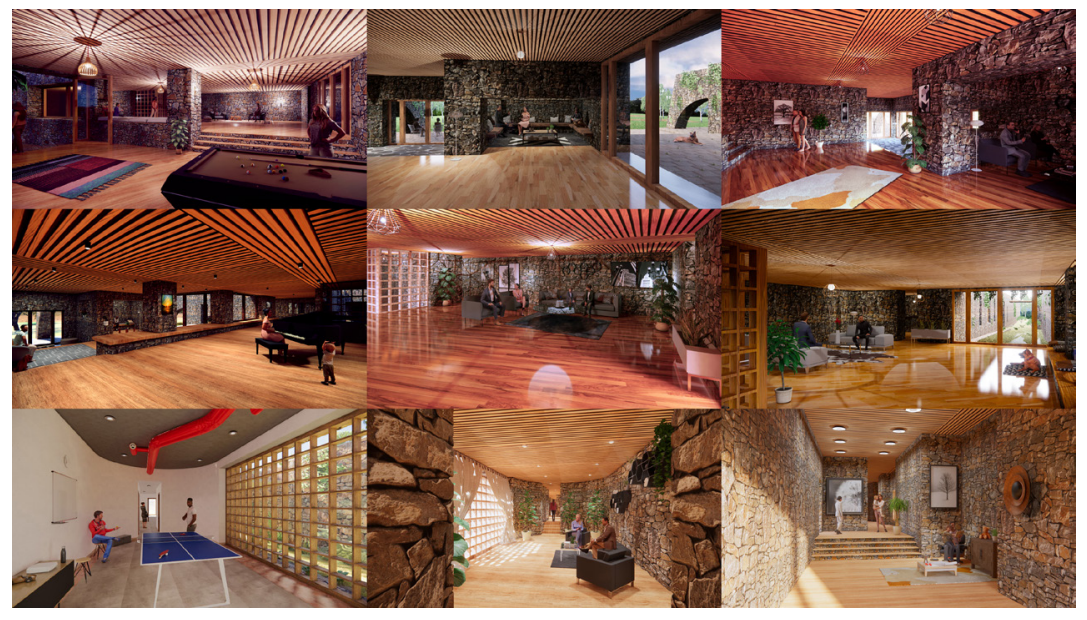

Ulteriori informazioni hanno riguardato le caratteristiche costruttive e materiche dell'edificio. In particolare, la possibilità di accedere a licenze educative, la compatibilità con i principali software di modellazione e la facilità di utilizzo, hanno portato alla scelta del plug-in di real time rendering e virtual reality Enscape della Enscape $\mathrm{GmbH}$, quale strumento per lo sviluppo di ipotesi ricostruttive di tipo fotografico della materialità attuale e pregressa della Coromandel House.

Con l'obiettivo di perseguire il paradigma informativo, che distingue propriamente un Building Information Model da un semplice modello tridimensionale, si è infine provveduto a categorizzare i "componenti" costruttivi individuati secondo una classificazione IFC 2×3 (fig. 2). È questa un'azione propedeutica all'esportazione del modello geometrico in formato IFC - Standard sviluppato dalla Building Smart, universalmente riconosciuto nelle applicazioni di tipo Open BIM: tale conversione rende il modello ispezionabile attraverso un qualsiasi visore gratuito disponibile online.

Uno standard di tipo aperto (Open BIM) è il fondamento per raggiungere la tanto agognata interoperabilità: lo scambio di informazioni basate su linguaggi e formati condivisi è la chiave per riuscire a ottimizzare ogni fase del lavoro, durante tutto il ciclo di vita di un edificio, rendendo il processo trasparente e pienamente collaborativo [Rossi 20 I9; Tchouangouem 20I9; <https://technical.buildingsmart.org> ].

Le immagini renderizzate sono dunque confluite in un repository online condiviso e accessibile a tutti, collegate al modello operando modifiche puntuali all'interno del codice testuale del file IFC. L'implementazione dei dati prodotti ha previsto quindi una fase di editing dello script del file IFC strutturato secondo la logica del data modeling language Express G.

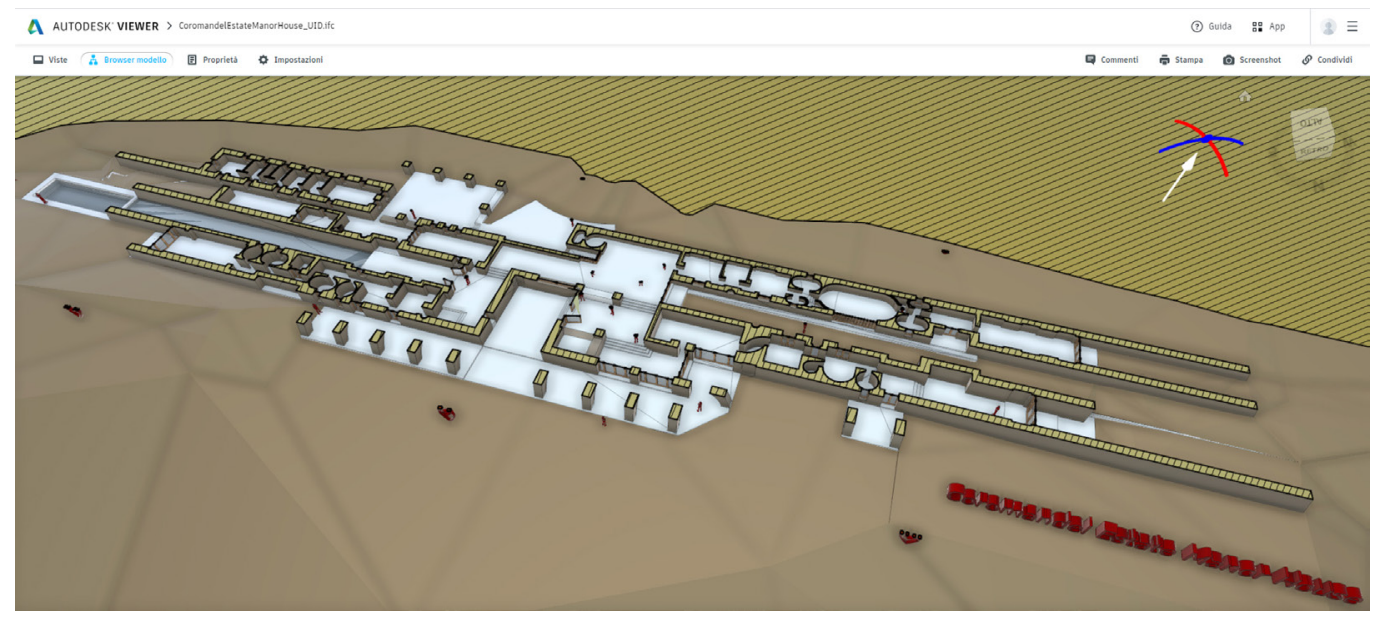

Fig. 8. Modello ispezionabile in formato IFC visualizzato tramite piattaforma online
Autodesk Viewer. 
Elementi modellati con sembianze umane fungono da appoggio per una disposizione, all'interno dell'opera d'architettura, di punti di vista privilegiati (Point of View), mentre Info Points sono funzionali all'accesso tanto all'ulteriore documentazione prodotta quanto a quella già disponibile online, ma fino ad ora non ancora organizzata in un unico database strutturato a servizio della pubblicizzazione dell'opera di Zanuso.

Non va dimenticato poi il richiamo alle Google Earth Coordinates e il relativo progetto KML for the localisation (fig. 3), inseriti quali ulteriori proprietà del contesto territoriale.

Editando lo script associato al file IFC è quindi possibile definire compiutamente anche proprietà preesistenti, completandone le descrizioni laddove necessario ed elevando così il LOI - Level of Information - associato. In figura (figg. 4, 5) si illustra la metodologia adottata per l'editing 'diretto' del modello in formato IFC [Zhang 20।4].

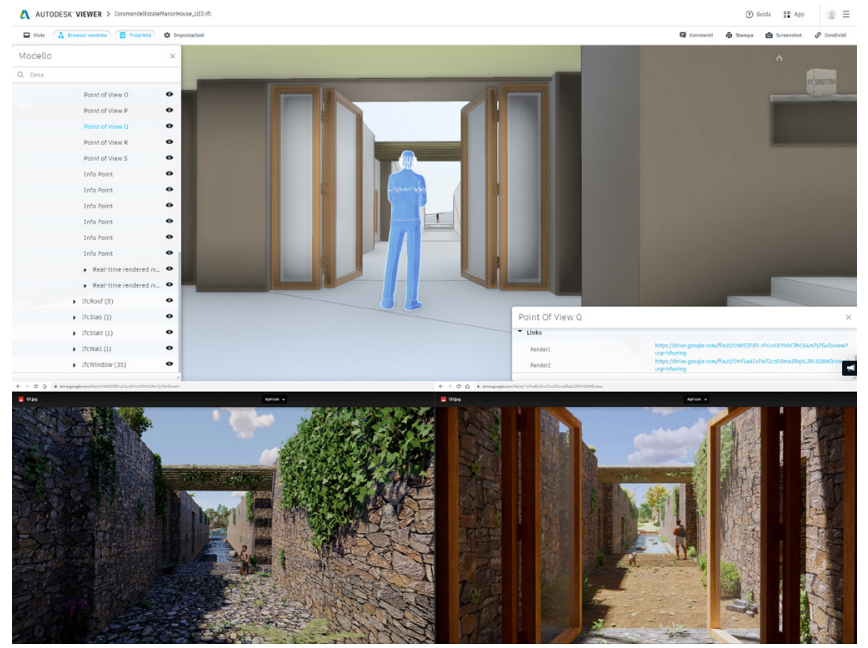

\section{Risultati}

A valle dell'esperienza didattica sono stati prodotti modelli geometrici con un LOD - Level of Development - 300 secondo la classificazione dell'American Institute of Architects o LOD C secondo la normativa italiana; in particolare, ogni studente ha sviluppato un proprio render per un totale di ventuno immagini (dodici degli esterni - fig. 6 e nove degli interni - fig. 7), definendo con cura la materialità degli elementi strutturali, la resa grafica, le luci, l'esposizione fotografica, e avendo cura di inserire elementi di arredo e figura umana per una contestualizzazione e quale riferimento metrico.

Si è quindi predisposto, secondo le modalità indicate, un repository informativo per la raccolta dei nuovi dati prodotti, procedendo poi a collegare questi dati, e quelli già disponibili online, al modello. Quest'ultimo, visualizzato attraverso piattaforma online (Autodesk Viewer - fig. 8) o applicativo per la visualizzazione di file IFC (BIM Vision) - entrambi gratuiti - funge da chiave di lettura grafica per la divulgazione della Coromandel Estate Manor House.

Nello specifico, le immagini online (Proprietà corrispondente: Weblmage), raccolte sotto la voce 'Links', sono state collegate agli elementi costruttivi in esse visibili, provvedendo inoltre alla compiuta definizione delle relative descrizioni.

Per i rendering sono stati disposti all'interno del modello elementi antropomorfi orientati concordemente alle viste prescelte cui collegare le relative immagini (Proprietà: 'Render' - fig. 9). Anche i documenti e le foto realizzate durante i viaggi di studio organizzati di concerto dalle tre università coinvolte sono stati collegati a modelli di info point (Proprietà: 'A travel journal', 'Paper' e 'Web Site' - fig. 10) omogeneamente disposti intorno all'oggetto architettonico. Punti informativi in formato volumetrico-testuale (Real-time rendered model - fig. II) sono stati infine disposti per il collegamento a due versioni del modello ispezionabili e percorribili esportati come Web Standalones, realizzati ancora una volta tramite l'applicativo Enscape. 
Fig. 10. Modello IFC con segnalazione di un Info Point e delle informazioni a esso collegate (Links).

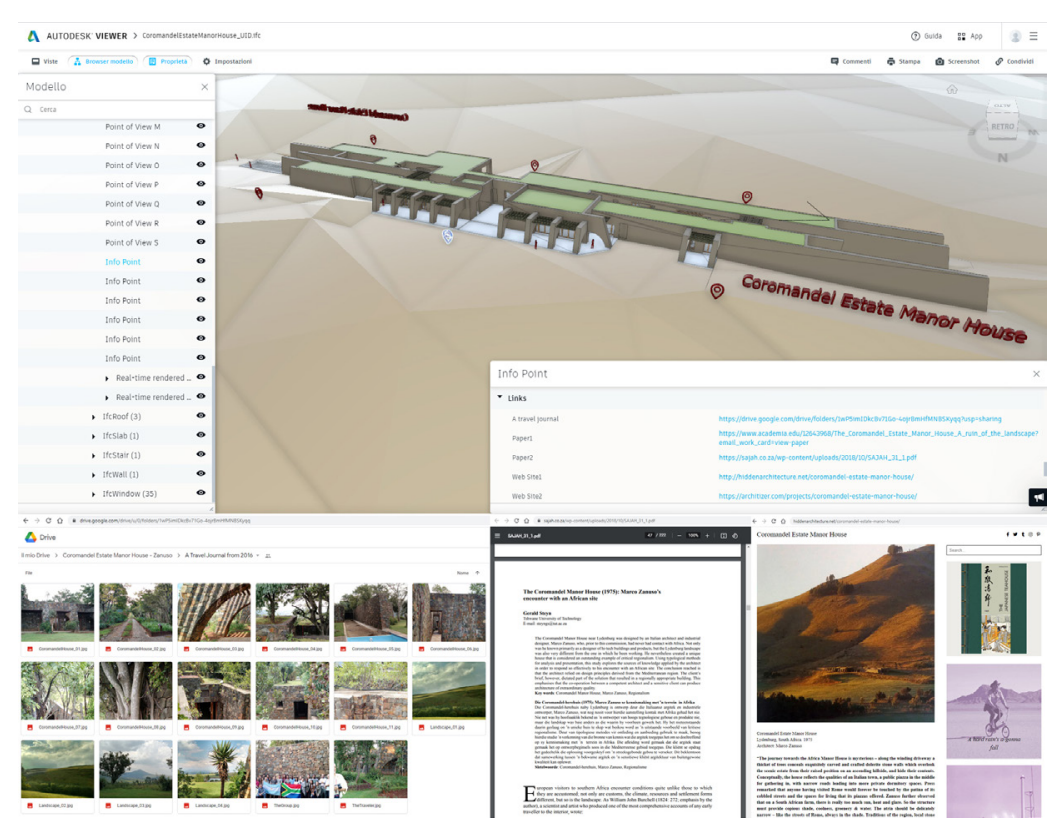

\section{Conclusioni}

Appare chiaro come l'utilizzo di tecnologie accessibili ai più sia riuscito a fare utilmente interagire tutti gli stakeholders coinvolti nel processo, dai docenti e ricercatori agli studenti (utenti finali dell'esperienza didattica), facilitando così uno scambio culturale e formativo continuo. L'impiego di metodologie tecniche pienamente condivise, quali l'approccio BIM adottato, e del linguaggio grafico che si fonda sul 'vocabolario' condiviso del disegno, hanno quindi consentito di superare barriere fisiche e distanze, in ciò includendo anche quelle culturali, in un processo che ha sicuramente arricchito tutte le parti coinvolte.

Si ricorda in ultima istanza l'importanza dell'adozione di un linguaggio di programmazione di facile comprensione per un approccio di tipo OpenBIM, che si configura come ulteriore strumento di condivisione accessibile.
Fig. I I. Modello IFC con segnalazione di un punto informativo volumetriinformativo volumetrico-testuale (Real-Time Rendered Model) e dei modelli Web Standalones a esso collegati (Model
Render).

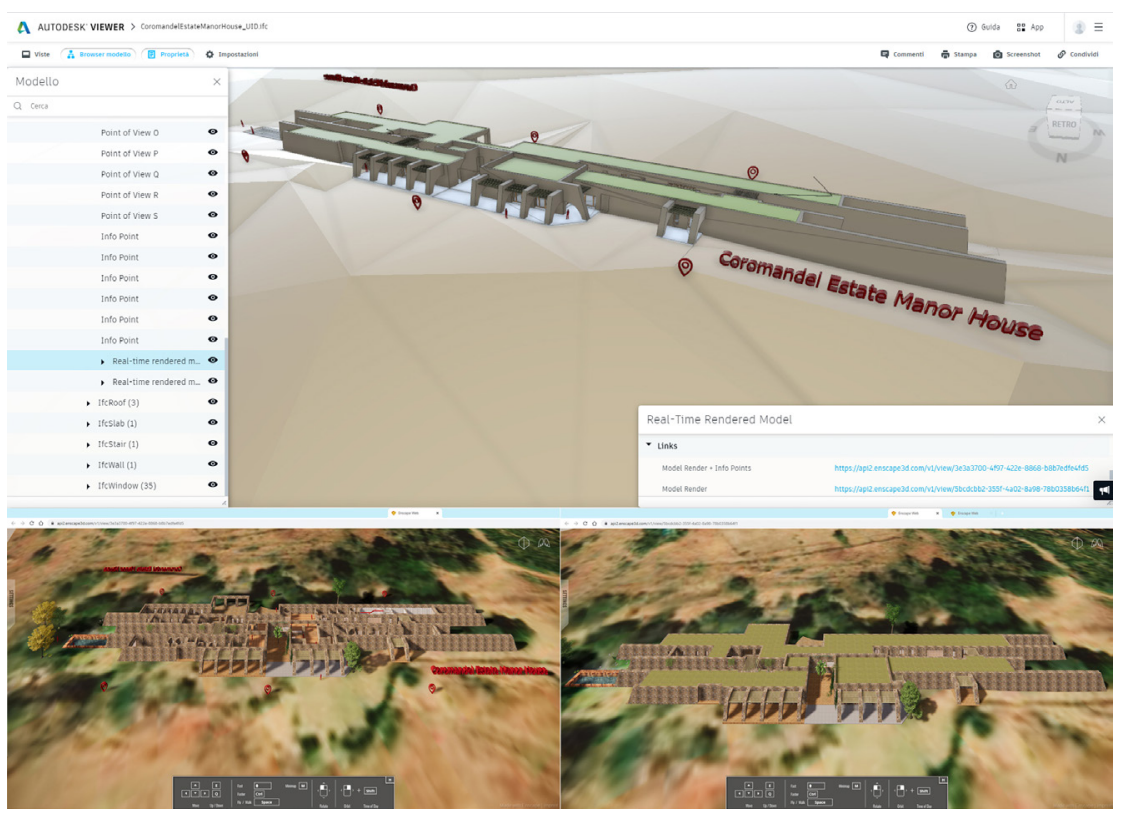




\section{Ringraziamenti}

Si ringraziano, per la collaborazione e la tempestiva condivisione del materiale in proprio possesso, i professori Jacques Laubscher (Dean of the Architectural Department), MostertVan Schoor (Professor of Survey) e Marinda Bolt (Professor of Design II) della Tshwane University of Technology di Pretoria.

\section{Note}

[I] La Coromandel Estate Manor House è stata scelta quale oggetto di studio a valle di un'esperienza che ha coinvolto I'Università degli Studi di Salerno, la Tshwane University of Technology di Pretoria e la Universidad Nacional de Córdoba, nell'ambito di attività di cooperazione internazionale finanziata con un progetto di mobilità - ISARP Italy-South Africa Joint Research Project.

\section{Riferimenti bibliografici}

Banfi F. et al. (2017). Historic BIM: A New Repository for Structural Health Monitoring. In ISPRS - International Archives of the Photogrammetry, Remote Sensing and Spatial Information Sciences, vol. XLII-5/WI, pp. 269-274.

Barba S., Ferreyra C., Laubscher J. (2016). Documentazione e valorizzazione del paesaggio culturale di Mpumalanga in Sudafrica. In Ferraris R. (ed.). Atti del VI Congreso Internacional de Expresión Gráfica en Ingeniería, Arquitectura y Carreras afines, Córdoba (Argentina), 22-24 settembre 2016, pp. 536-542.

Calvano M., Guadagnoli F. (20 16). 3D Reconstrution of the city of Amatrice. An "instant modeling" operation. In Disegnarecon, vol. 9, n. I7, pp. 7.1 -7.9

Comisión es.BIM (20 I 8). Guía para la elaboración del Plan de Ejecución BIM (BEP). España: Gobierno de España.

Lo Turco M. (20 I I). II Building Information Modeling, tra ricerca, didattica e professione. In Disegnarecon, vol. 4, n. 7, pp. 42-5 I.

Osello A. (20 I2). II futuro del disegno con il BIM per ingegneri e architetti, The future of Drawing with BIM for Engineers and Architects. Palermo: Dario Flaccovio Editore.

Peres E. (20|3). The Coromandel Estate Manor House: A 'ruin' of the landscape. In Architecture South Africa, issue 62, pp. 32-37.

Rossi A., Palmieri U. (2019). LOD per il patrimonio architettonico: la modellazione BIM per la fabbrica Solimene. In diségno, n. 4, pp. $213-224$.

Sacchi L. (20 16). II punto sul B.I.M. In Disegnarecon, vol. 9, n. I6, 20 I6. ISSN: I828-596I.

Sacks R. et al. (20 I 8). BIM Handbook: A Guide to Building Information Modeling for Owners, Designers, Engineers, Contractors, and Facility Managers. 3rd Edition. Hoboken, New Jersey: John Wiley \& Sons, Inc.

Steyn G. (2016). The Coromandel Manor House (1975): Marco Zanuso's encounter with an African site. In South African Journal of Art History - SAJAH, vol. 31 , n. I, pp. 38-54.

Tchouangouem J.F. et al. (2019). Integration of environmental data in BIM tool \& Linked Building Data. In Poveda V. et al. (eds.) Proceedings of the 7th Linked Data in Architecture and Construction Workshop, LDAC 2019. Lisbona, I 7-21 giugno 20 I9, pp. 78-91.

Yousefzadeh S. et al. (20I5). Building Information Modelling (BIM) Software Interoperability: A Review of the Construction Sector. In Raiden A.B., Aboagye-Nimo E. (eds.). Proceedings of the 3 I st Annual ARCOM Conference, ARCOM, 20 I 5, Lincoln, UK, 7-9 September 20 15, pp. 71 1-720. UK: Association of Researchers in Construction Management.

Zhang C., Beetz I., Weise M. (20/4). Model view checking: automated validation for IFC building models. In Mahdavi A., Martens B., Scherer R. (2014). eWork and eBusiness in Architecture, Engineering and Construction - Proceedings of the 10th European Conference on Product and Process Modelling, ECPPM 2014,Vienna 17-19 settembre 2014, pp. I23- I28. Boca Raton: CRC Press.

\section{Sitografia}

<https://architizer.com/projects/coromandel-estate-manor-house/> (consultato il 24 febbraio 202I)

<http://hiddenarchitecture.net/coromandel-estate-manor-house/> (consultato il I 8 gennaio 202I)

$<$ https://technical.buildingsmart.org/> (consultato il 24 febbraio 202l)

\section{Autori}

Anna Sanseverino, Università degli Studi di Salerno, asanseverino@unisa.it

Victoria Ferraris, Universidad Nacional de Córdoba, victoria.ferraris@unc.edu.ar

Davide Barbato, Università degli Studi di Salerno, dbarbato@unisa.it

Barbara Messina, Università degli Studi di Salerno, bmessina@unisa.it

Per citare questo capitolo: Sanseverino Anna, Ferraris Victoria, Barbato Davide, Messina Barbara (202I). Un approccio collaborativo di tipo BIM per colmare distanze fisiche, sociali e culturali/A BIM collaborative spproach to overcome physical, social, and cultural distances. In Arena A., Arena M., Mediati D., Raffa P. (a cura di). Connettere. Un disegno per annodare e tessere. Linguaggi Distanze Tecnologie. Atti del $42^{\circ}$ Convegno Internazionale dei Docenti delle Discipline della Rappresentazione/Connecting. Drawing for weaving relationship. Languages Distances Technologies. Proceedings of the $42^{\text {th }}$ International Conference of Representation Disciplines Teachers. Milano: FrancoAngeli, pp. | | $8|4-183|$. 


\title{
A BIM Collaborative Approach to Overcome Physical, Social and Cultural Distances
}

\author{
Anna Sanseverino \\ Victoria Ferraris \\ Davide Barbato \\ Barbara Messina
}

Abstract

The paper presents a didactic experience firstly addressed at the students of the Computer Graphics course of the Building Engineering-Architecture Degree Programme at the University of Salerno, concerning the representation of integrated data with a BIM approach. Distance learning has become mandatory given the actual sanitary emergency and, in this case, it became a mean to test the possibility of an active international and intercollegiate collaboration between 'South of Italy - South America - South Africa', by summoning both teachers and students up to deal with the challenge of group work while still self-isolating. The selected case study is the South-African Coromandel House, by Marco Zanuso - regarded as one of the founding fathers of Italian design - with the aim of developing repository type of models. The proposed application method: started from a cooperative modelling phase followed by a rendering phase carried out by employing user-friendly tools. The final graphics, together with the pre-existing documentation, became part of an informative database linked to the 3D model, using an OpenBIM approach for further dissemination and in order to promote a continuous cultural and educational exchange.

Keywords

languages, technical methodology, open BIM, IFC, Coromandel House.

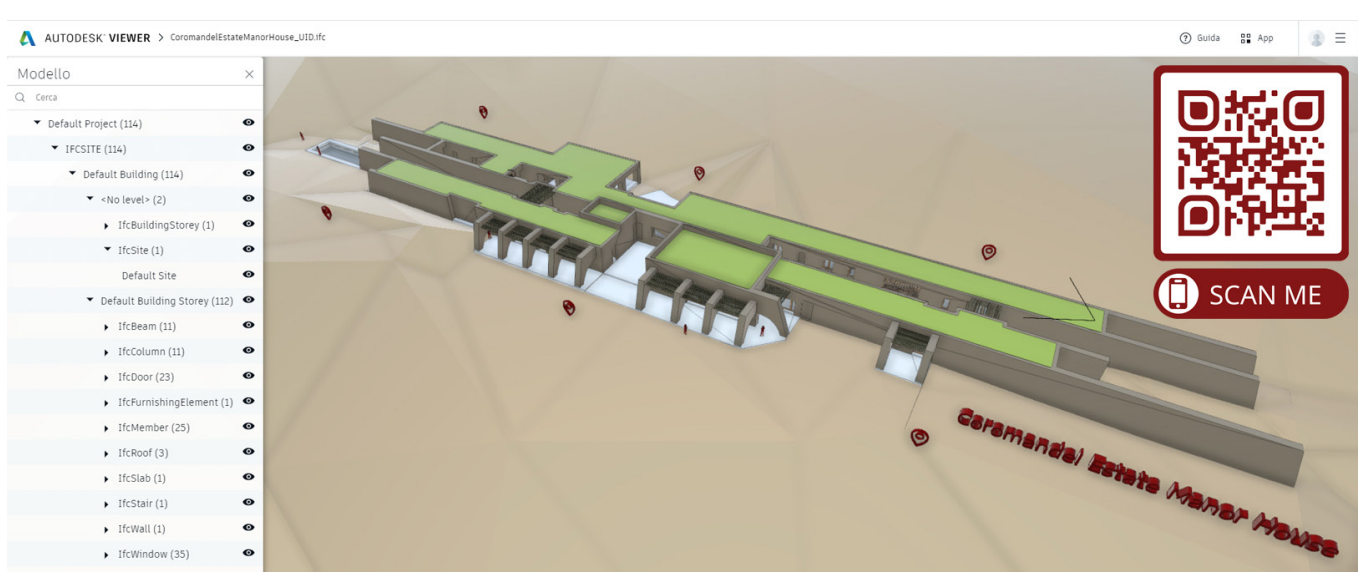




\section{Introduction}

The present work represents a moment of reflection resulting from the didactic experience of the Computer Graphics course of the Building Engineering-Architecture Degree Programme at the University of Salerno, that involved both the Italian drawing professors and visiting professors from the National University of Córdoba. The purpose of the course was to introduce future architects and engineers to the BIM technical methodology.

The educational value of developing graphic and project expertise of the students through a BIM approach is a well-known topic of discussion. The research carried out on the topic [Banfi 2017; Calvano 2016; Osello 20 2; Sacchi 20 I6] especially concerns the new possibilities provided by the BIM methodology, i.e., the capability of not just visualizing the three-dimensional space as a volumetry but also as an ensemble of its constructive elements. At the same time, the interoperability between information and linked data allows BIM to improve students' collaborative skills, in order for them to learn how to work in a participative and integrated way [LoTurco 201।;Yousefzadeh 2015].

The Coromandel Estate Manor House [https://architizer.com; http://hiddenarchitecture.net], built in South Africa and designed by Italian architect Zanuso, constitutes a suitable case study to analyse the results produced by a mixture of different cultures and to test the proposed approach (fig. I).

In particular, this study aims at analysing masonry structures, belonging to the local traditional constructive technology, with the support of modern investigation tools and, at the same time, reconciling complementary but somehow opposite disciplines, i.e., engineering and architecture. Moreover, this academic exercise confirmed the importance of group work, of an interdisciplinary approach and of the benefits of using the BIM (Building Information Modelling) methodology as an analysis and research tool [Comisión es.BIM 20 I8].

The proposed graphical method involved a simplified approach, directly starting with the modelling of the artefact in a Sketch Up environment. A first informative layer was added to the geometric model by texturizing the constructive elements. Consequentially a number of renders was individually produced by each student, employing the Enscape plug-in for SketchUp. The resulting graphic drawings were included -together with the pre-existing written, graphic, photographic, public, and unpublished documentation regarding the site- in an informative system linked to the three-dimensional model, thus operating in compliance with the BIM technology [Sacks et al. 2018].

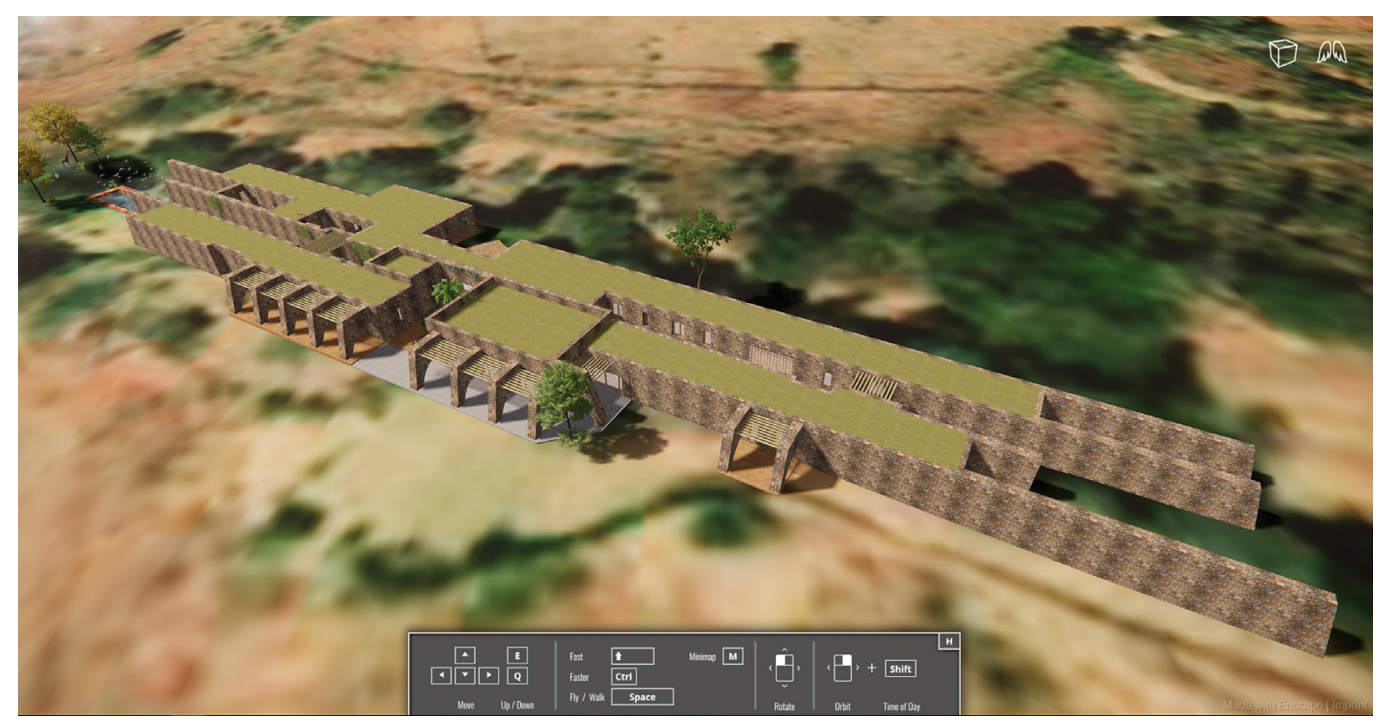




\section{The architectural artefact}

Italian architect and industrial designer Marco Zanuso succeeded in interpreting the South-African landscape, clime, and local constructive technology of the Mpumalanga region [Barba 20I6], by means of research and exploration of different typological solutions, in order to transform his project in a proposal that includes both the built environment and the surroundings [Steyn 2016]. By combining the environmental requirements -i.e., climatic conditions- with the client requests, he managed to originally and efficiently deal with the private residence topic, so the product becomes a masterful example of the South-African regional architecture.

The Coromandel Estate Manor House is the combination of a South-African client's dreams, his strong fascination for architecture, and the sensitive answer of a designer, who was able to interpret a culture different from his own, making it into a remarkable artwork. It manages to make two different worlds, with their idiosyncrasies and belonging two opposite fields of study, interact resulting into an optimal solution not only to the architectural problem, but also to the environmental and climatic one.

"The journey towards the Africa Manor House is mysterious - along the winding driveway a thicket of trees conceals exquisitely carved and crafted dolerite stone walls which overlook the scenic estate from their raised position on an ascending hillside and hide their contents. Conceptually, the house reflects the qualities of an Italian town, a public piazza in the middle for gathering in, with narrow roads leading into more private dormitory spaces. On a South-African farm, there is really too much sun, heat and glare. So, the structure must provide copious shade, coolness, greenery and water.The house can be described as a dramatic manipulation of the landscape that offers practical, periodic shelter within its organised spaces and rational lines" [Peres 20 I3].

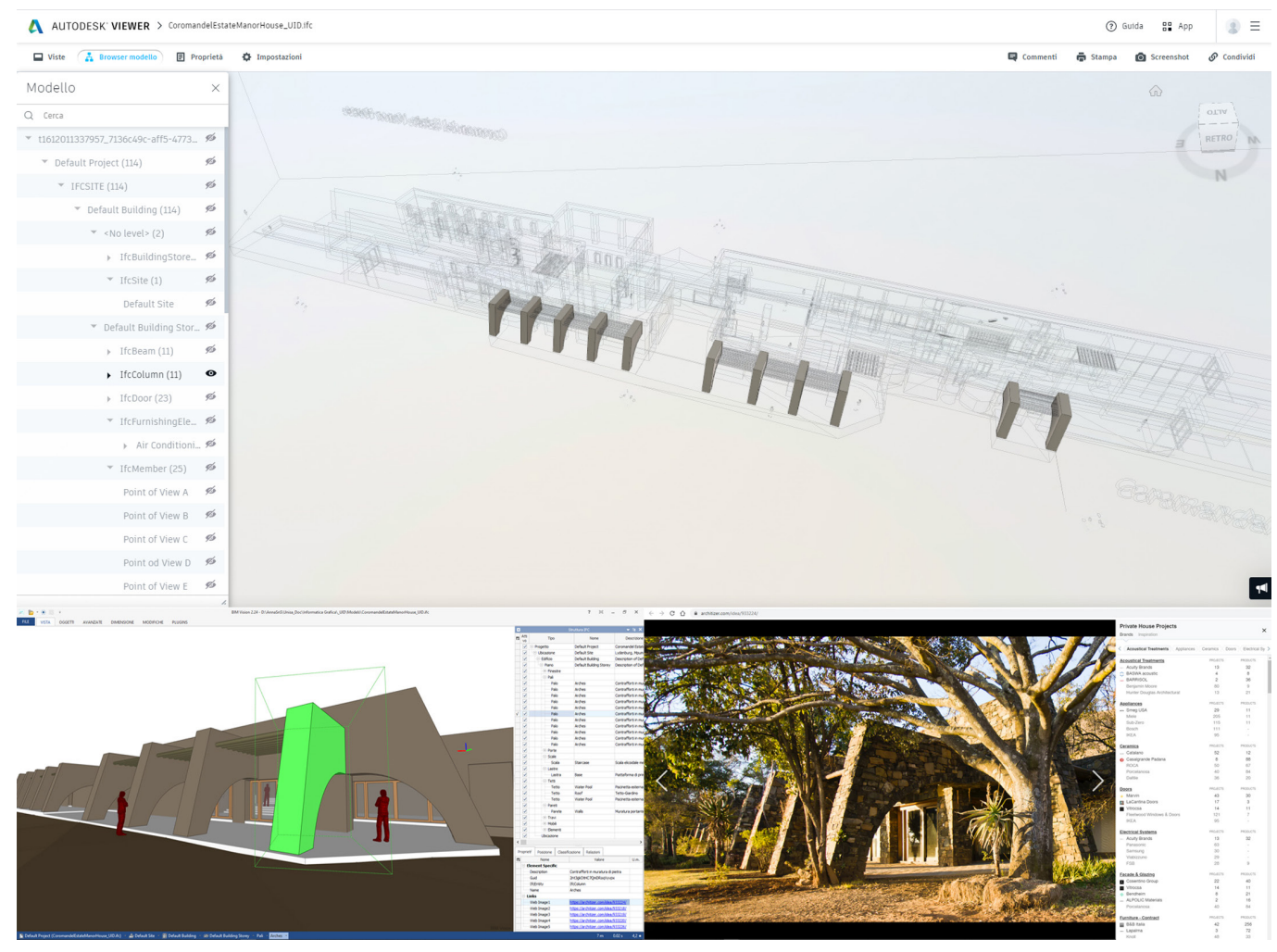

\section{Methods: the work environment}

The current sanitary emergency undoubtedly fostered the informatization process of the entire educational system, relying on a multiplicity of already-online platforms and the related tools. Although this situation tore us apart, the currently available technology 
Fig. 3. Territorial context as IfcSite with the related connected properties (Links).

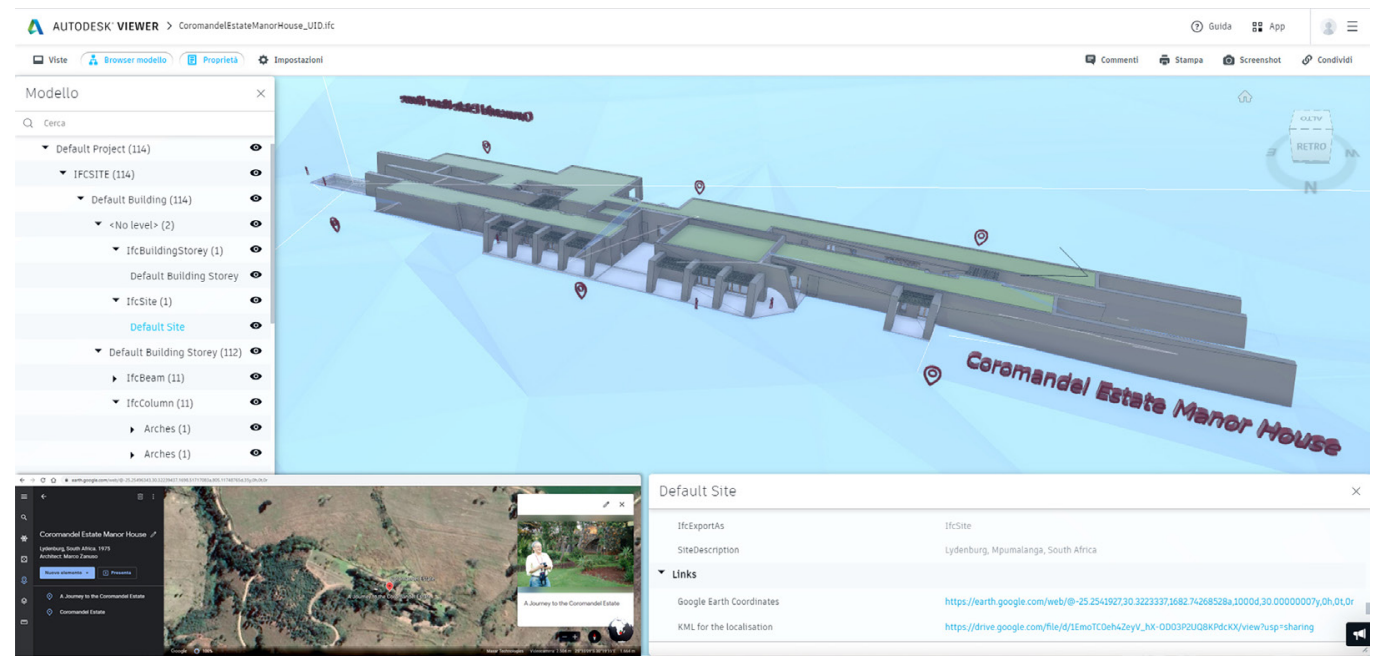

brought to light the advantages connected to distance-learning modalities and tools, that had been left almost unutilized by the traditional Athenaeums. First of all, these tools make it possible to draw digitally close their users, that will therefore freely share data and information in real-time, in compliance with interoperability principles. The Microsoft Teams platform was selected for lectures, practical and laboratory activities addressed at the third-year students of the Building Engineering-Architecture Degree Programme at the University of Salerno. On one hand, this didactic experience turned out highly effective on a practical and operational level, thus allowing the sharing of graphics, images, and all kind of information related to the architectural asset chosen to test the proposed digital approach; on the other hand, it made it possible to overcome the physical distance between 3 countries -Italy, Argentine, and South Africa- which had already been involved in a international cooperation project [ $\mathrm{I}]$ and had then found a 'common ground' to meet and communicate.

The data collected during several joined visits - which took places before the global sanitary emergency- made by students and teachers from all involved universities were digitally shared to let the students further explore the site and the architectural artefact to represent. The selected software was Trimble SketchUp, keeping in mind the economic accessibility -given its reasonable cost, it is indeed considered affordable by a larger market segment, including amateurs- the friendly graphical user interface, its wide-spreading, and its compatibility with most of the commercial rendering engines. It was also considered the possibility provided by SketchUp to model according to the principles of a BIM technical application just by making small adjustments and accurately selecting the tools to employ.

$\# 000000=$ IFCMEMBER ('0N6rCs7ED2mhzs4NjoASLs', $\$ 2$, 'Point of View N', 'Punto d vista rendering', \$, \#456181, \#456186, \$)

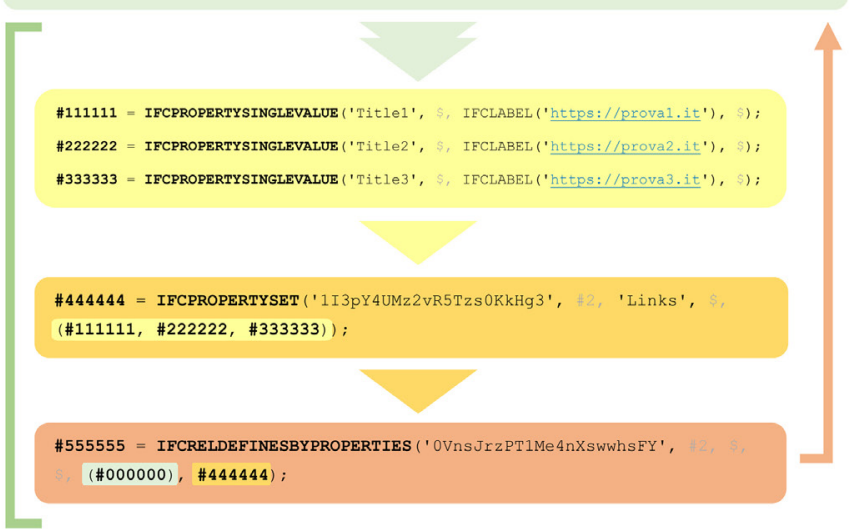

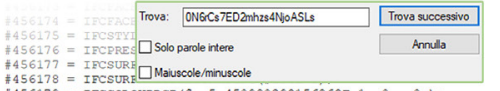

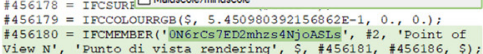

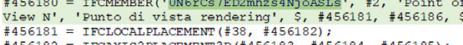

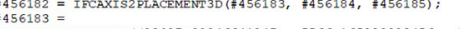
IFCCARTESTANPOINT ( (28027.90946641247, -5566.165989228456, -564 $.882107647359)$;
$456184=$ IFCDIRECTION $((0 ., 0 ., 1)$.

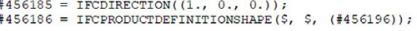

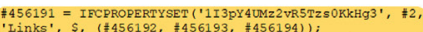

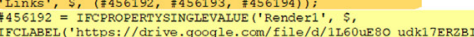

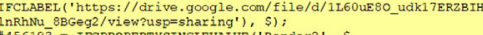

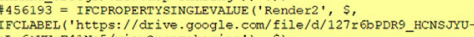

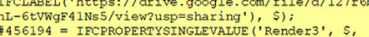

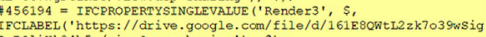

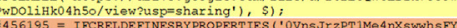

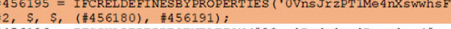

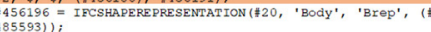

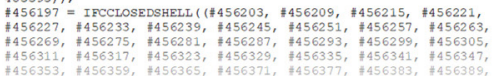

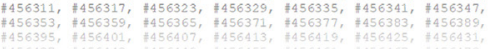


Fig. 5. Result of the IFC editing for the connection of the renders to the Points of View placed in the model.

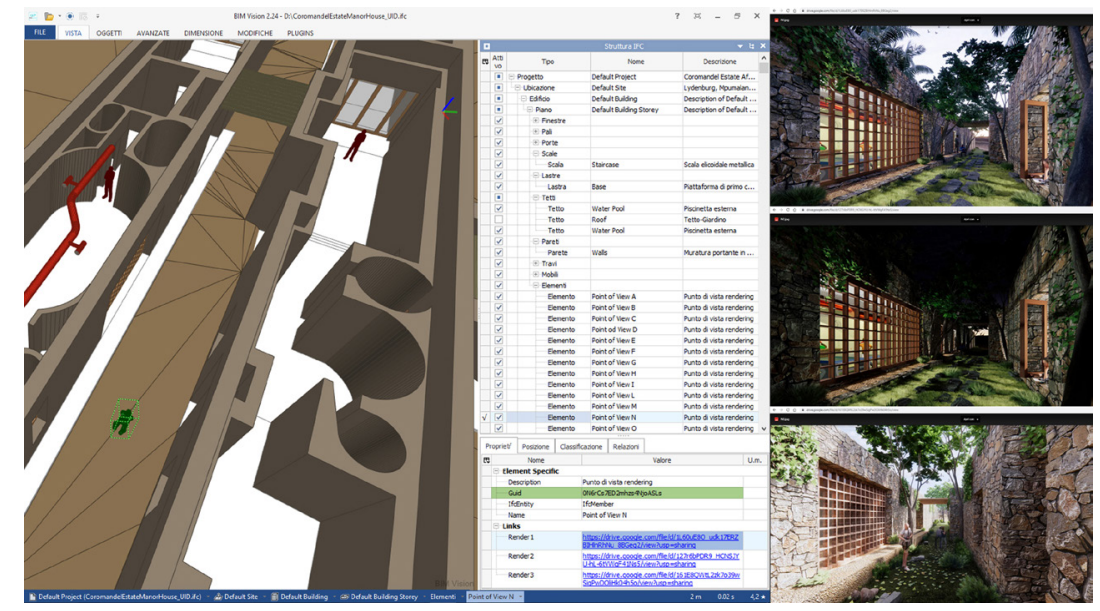

An approach that complies with a BIM technical methodology

Given the peculiar characteristics of the case study, its structural irregularities, the high anisotropy of internal spaces, and the materiality that seems to both emerge from and blend with the environment, it resulted objectively convenient to use such software. It was indeed pretty easy to model the complex geometries of the built environment and the context to represent.

The collaborative approach undoubtedly followed the principles of the BIM methodology: an object-oriented, parametric, and informative modelling process. To this purpose, the constitutive elements of the Estate Manor were discretized and organised in components, according to the object-oriented paradigm. Free tools, that operates within the chosen software environment, were employed to parametrically model finishing elements, because of the higher level of detail required, i.e., windows frames and helicoidal staircase, leaving them easily resizable at any moment.

The first piece of information added to the model was the georeferencing, by directly accessing from SketchUp to the available Google map: thus, in the contextualisation stage, it was digitally reproduced the, albeit simplified, topography of the site.

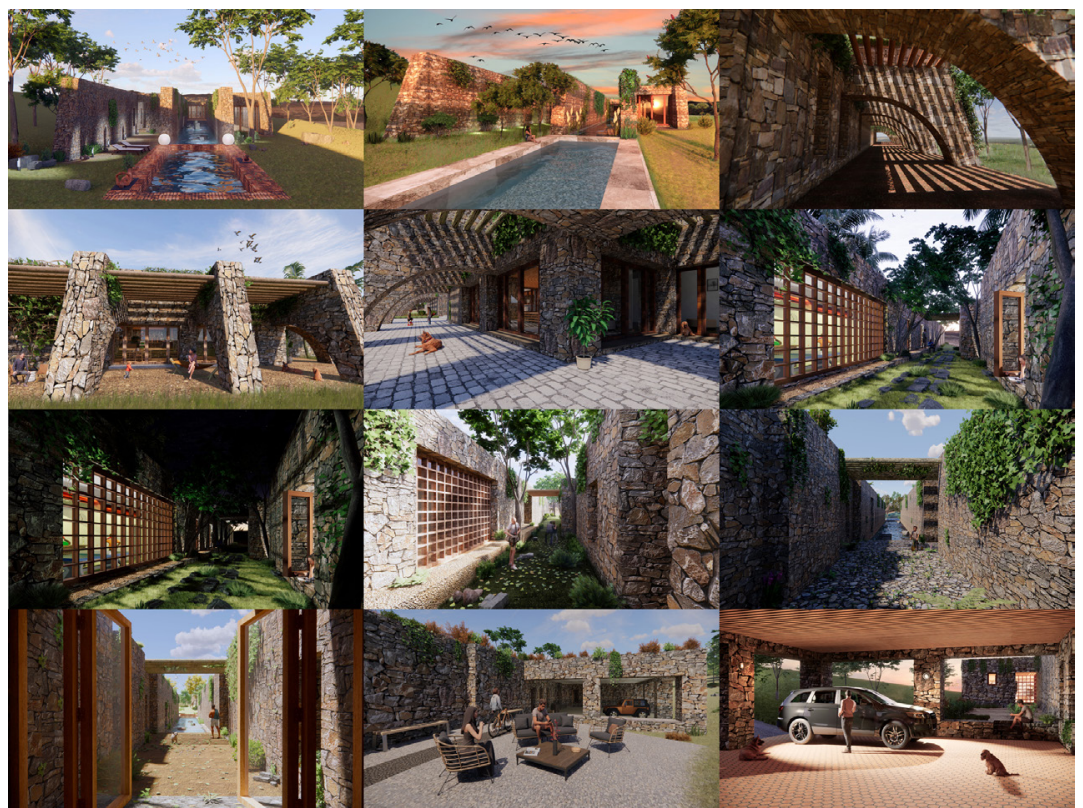


Fig. 7. Interior rendered images individually produced by the students

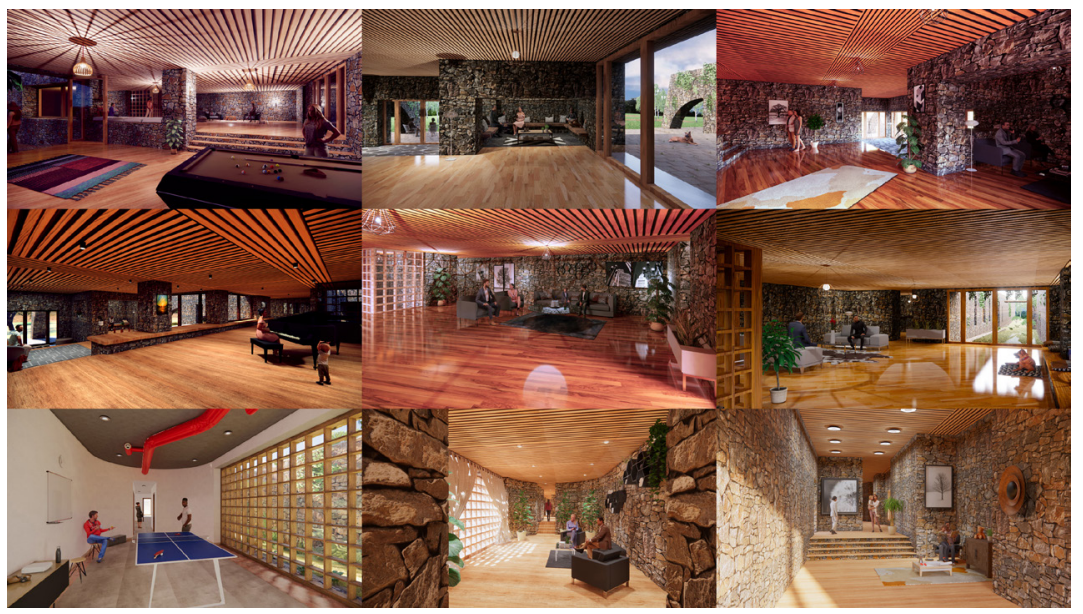

Further detailed information regarded the constructive and material characteristics of the asset. Having then the chance to request educational licences, the real-time-rendering and virtual-reality plug-in Enscape by Enscape $\mathrm{GmbH}$ was opted for as a tool to develop photorealistic reconstructive hypotheses of the actual and past materiality of the Coromandel House.

Keeping in mind the informative paradigm, which properly distinguish a Building Information Model from a simple three-dimensional one, the digital artefact was then organised into constructive 'components' in accordance with the IFC $2 \times 3$ classification (fig. 2).

This procedure is propaedeutic to export the geometric model to IFC - which is a standard developed by Building Smart and universally accepted for the Open BIM applications: this kind of conversion let anyone examine the model just by employing a free viewer among those ones available online. An Open BIM standard lays the foundation for reaching the so longed-for interoperability: the exchange of information on the basis of shared languages and formats is key to optimize each work phase, throughout the entire life cycle of a building, aiming at a transparent and fully collaborative process [Rossi 2019; Tchouangouem 2019; <https://technical.buildingsmart.org>].

The rendered images were then incorporated into an online shared repository, that was made available for everyone; then they were linked to the model by making specific adjustments to the textual code of the IFC file. For the implementation of the elaborated data, it was then necessary to edit the script of the IFC file, which is usually structured according to the logic of the Express $G$ data modeling language.

Elements modelled with human shapes were used to place, throughout the architectural artefact, privileged Point of View, while the Info Points had the purpose to give

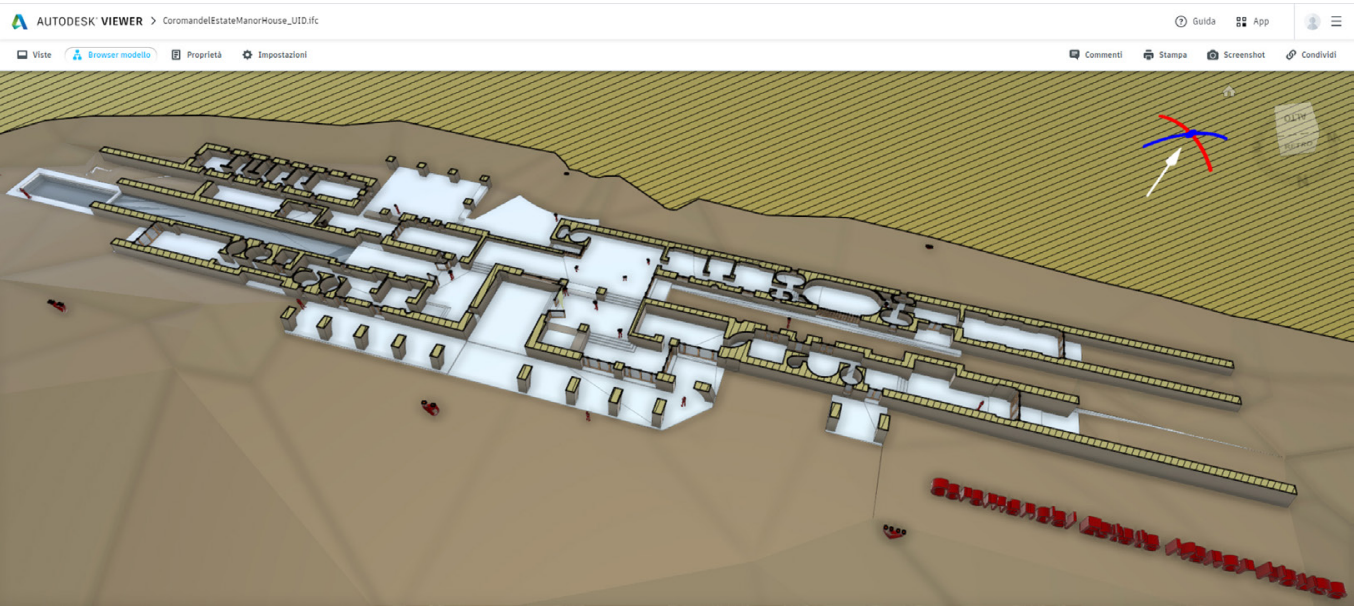


access to the external documentation, including both the one produced at the end of the present application and that one already available online, but not yet organised as a structured database for the dissemination of Zanuso's work.

It should then be mentioned the reference made to the Google Earth Coordinates and the related KML for the localisation project (fig. 3) as they were added as additional properties to the territorial context.

By editing the script of the IFC file was therefore possible to properly redefine the pre-existing properties, so to complete their descriptions as necessary and improve the associated LOI - Level of Information. In figure (figs. 4, 5) it is shown the methodology applied for directly editing the IFC model [Zhang 20I4].

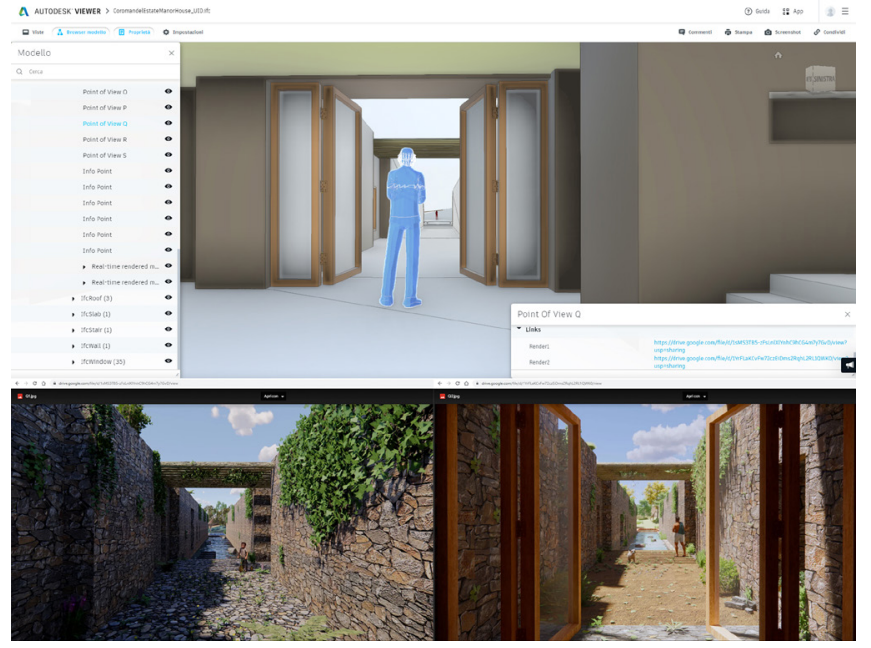

\section{Results}

The result produced by this didactic experience was a number of geometric models that qualify as LOD - Level of Development-300, according to the American Institute of Architects classification, or LOD C, in compliance with the Italian regulation; in detail, each student developed his own render for a total of twenty-one images (twelve of the exteriors -fig. 6 and nine of the interiors- fig. 7), taking care to accurately define the texture of the structural elements, the graphic rendering, the lighting, the photographic exposure, and to add furnishing and human figures, i.e., those elements used to accomplish the contextualization and to serve as a metric reference.

An informative repository, for harvesting newly produced data, was set up as indicated; said data, together with the already available ones, were subsequently linked to the model. The resulting model, that can be inspected using an online platform (Autodesk Viewer - fig. 8) or a downloadable application for IFC visualisation (BIMVision) -both free- serve as graphic reading key intended for the dissemination of the Coromandel Estate Manor House.

Specifically, the online images (Corresponding property: 'Weblmage'), gathered under the 'Links' identification, were each attached to the constructive elements represented in them, hence it was time to completely define the related descriptions.

The rendered images were linked to anthropomorphic elements distributed across the model and oriented in accordance with the points of view from where said images were taken (Property: 'Render' - fig. 9).

The documents and the photographs taken during the educational trips jointly organised by all three involved universities were linked to modelled info points (Property: 'A travel journal', 'Paper' e 'Web Site' - fig. 10) that were evenly placed around the architectural asset. A pair of textual-volumetric info points (Real-time rendered model - fig. I I) were eventually laid to provide an access to two inspectable and navigable versions of the model exported as Web Standalones and realised thanks to the Enscape plug-in. 
Fig. I0. IFC model with highlighting of an Info Point and the linked information (Links).

Fig. I I. IFC model with highlighting of a textualvolumetric info point Real-Time Rendered Model) and the linked Web Standalones model (Model Render).

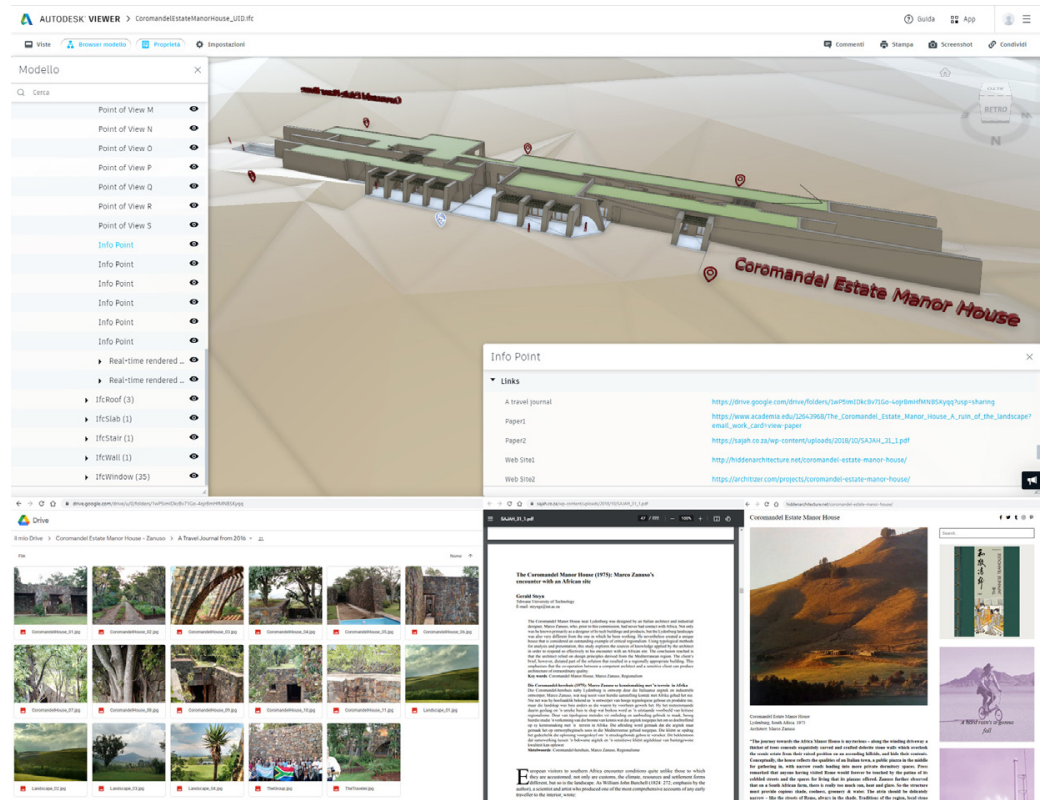

\section{Conclusions}

It becomes clear that the employment of accessible technologies allowed all the stakeholder, i.e., professors, researchers, and students (as the end-users of the didactic experience), to profitably interact, so to encourage a continuous cultural and educational exchange. Using generally accepted technical methodology, such as the BIM approach here proposed, and the graphic language based on the drawing shared 'vocabulary', made it possible to overcome distances and physical barriers, including the cultural ones, as part of a process capable to enrich all the parties involved.

Eventually, implementing an easy-to-understand programming language for an Open BIM approach is to be considered as an additionally accessible sharing tool.

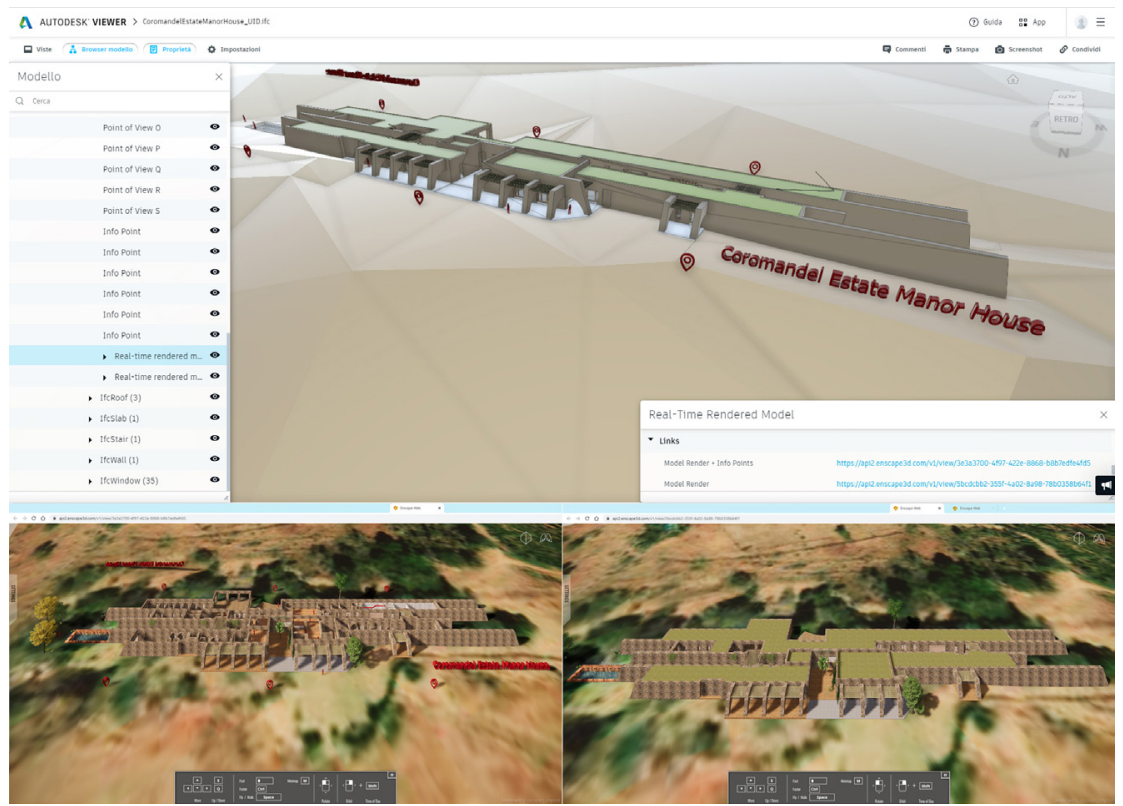




\section{Acknowledges}

We would like to thank professors Jacques Laubscher (Dean of the Architectural Department), Mostert Van Schoor (Professor of Survey) and Marinda Bolt (Professor of Design II) of the Tshwane University of Technology of Pretoria, for the cooperation and the prompt sharing of the documents in their possession.

\section{Notes}

[I]The Coromandel Estate Manor House was selected as case study because of an experience that involved the University of Salerno, the Tshwane University of Technology of Pretoria, and the National University of Córdoba, in the internationally founded cooperation activities of the mobility project - ISARP Italy-South Africa Joint Research Project.

\section{References}

Banfi F. et al. (2017). Historic BIM: A New Repository for Structural Health Monitoring. In ISPRS - International Archives of the Photogrammetry, Remote Sensing and Spatial Information Sciences, vol. XLII-5/WI, pp. 269-274.

Barba S., Ferreyra C., Laubscher J. (2016). Documentazione e valorizzazione del paesaggio culturale di Mpumalanga in Sudafrica. In Ferraris R. (ed.). Atti del VI Congreso Internacional de Expresión Gráfica en Ingeniería, Arquitectura y Carreras afines, Córdoba (Argentina), 22-24 settembre 2016, pp. 536-542.

Calvano M., Guadagnoli F. (20 I6). 3D Reconstrution of the city of Amatrice. An "instant modeling" operation. In Disegnarecon vol. 9, n. 17, pp. 7.1-7.9.

Comisión es.BIM (20 I 8). Guía para la elaboración del Plan de Ejecución BIM (BEP). España: Gobierno de España.

Lo Turco M. (20 I I). II Building Information Modeling, tra ricerca, didattica e professione. In Disegnarecon, vol. 4, n. 7, pp. 42-5 I.

Osello A. (2012). Il futuro del disegno con il BIM per ingegneri e architetti, The future of Drawing with BIM for Engineers and Architects. Palermo: Dario Flaccovio Editore.

Peres E. (2013). The Coromandel Estate Manor House: A 'ruin' of the landscape. In Architecture South Africa, issue 62, pp. 32-37.

Rossi A., Palmieri U. (2019). LOD per il patrimonio architettonico: la modellazione BIM per la fabbrica Solimene. In diségno, $n$. 4, pp. 2 13-224.

Sacchi L. (2016). II punto sul B.I.M. In Disegnarecon, vol. 9, n. I6, 20 I6. ISSN: I 828-596।

Sacks R. et al. (20 I 8). BIM Handbook: A Guide to Building Information Modeling for Owners, Designers, Engineers, Contractors, and Facility Managers. 3rd Edition. Hoboken, New Jersey: John Wiley \& Sons, Inc.

Steyn G. (2016). The Coromandel Manor House (1975): Marco Zanuso's encounter with an African site. In South African Journal of Art History - SAJAH, vol. 31 , n. I, pp. 38-54.

Tchouangouem J.F. et al. (20।9). Integration of environmental data in BIM tool \& Linked Building Data. In Poveda V. et al. (eds.) Proceedings of the 7th Linked Data in Architecture and Construction Workshop, LDAC 2019. Lisbona, I7-21 giugno 2019, pp. 78-91.

Yousefzadeh S. et al. (20I5). Building Information Modelling (BIM) Software Interoperability: A Review of the Construction Sector. In Raiden A.B., Aboagye-Nimo E. (eds.). Proceedings of the 3 I st Annual ARCOM Conference, ARCOM, 20 I 5, Lincoln, UK 7-9 September 20 15, pp. 71 1-720. UK: Association of Researchers in Construction Management.

Zhang C., Beetz J., Weise M. (20|4). Model view checking: automated validation for IFC building models. In Mahdavi A., Martens B., Scherer R. (2014). eWork and eBusiness in Architecture, Engineering and Construction - Proceedings of the 10th European Conference on Product and Process Modelling, ECPPM 201 4,Vienna 17 - 19 settembre 2014 , pp. I 23- I 28. Boca Raton: CRC Press.

\section{Website}

<https://architizer.com/projects/coromandel-estate-manor-house/> (accessed 202 I, February 24).

<http://hiddenarchitecture.net/coromandel-estate-manor-house/> (accessed 202I, February I8).

<https://technical.buildingsmart.org/> (accessed 2021, February 24).

\section{Authors}

Anna Sanseverino, Università degli Studi di Salerno, asanseverino@unisa.it

Victoria Ferraris, Universidad Nacional de Córdoba, victoria.ferraris@unc.edu.ar

Davide Barbato, Università degli Studi di Salerno, dbarbato@unisa.it

Barbara Messina, Università degli Studi di Salerno, bmessina@unisa.it

To cite this chapter. Sanseverino Anna, Ferraris Victoria, Barbato Davide, Messina Barbara (202I). Un approccio collaborativo di tipo BIM per colmare distanze fisiche, sociali e culturali/A BIM collaborative spproach to overcome physical, social, and cultural distances. In Arena A. Arena M., Mediati D. Raffa P. (a cura di). Connettere. Un disegno per annodare e tessere Linguaggi Distanze Tecnologie. Atti del $42^{\circ}$ Convegno Internazionale dei Docenti delle Discipline della Rappresentazione/Connecting. Drawing for weaving relationship. Languages Distances Technologies. Proceedings of the $42^{\text {th }}$ International Conference of Representation Disciplines Teachers. Milano: FrancoAngeli, pp. I8 | $4-183 \mid$. 